\title{
The Dogger Bank: a special ecological region in the central North Sea
}

\author{
I. Kröncke ${ }^{1} \&$ R. Knust ${ }^{2}$ \\ ${ }^{1}$ Forschungsinstitut Senckenberg, Schleusenstr. 39a; 26382 Wilhelmshaven, Germany \\ ${ }^{2}$ Alfred-Wegener-Institute for Polar and Marine Research; 27515 Bremerhaven, Germany
}

\begin{abstract}
This paper is a review of the present state of knowledge about the ecology of the Dogger Bank, a shallow area in the central southern North Sea. The biological situation in this region is different from other regions in the North Sea; phytoplankton production occurs throughout the year, connected with low periodicity in macrofaunal abundance and condition of fish. Against prevailing opinions, the Dogger Bank, an offshore region, seems to be affected by eutrophication and pollution.
\end{abstract}

\section{INTRODUCTION}

The Dogger Bank is a shallow water area in the southern central North Sea, $300 \mathrm{~km}$ in extension (Fig. 1). About 8000 years ago, this bank was the southern border of the North Sea. Depths range between 18 and $40 \mathrm{~m}$. The Dogger Bank is influenced by Atlantic water masses coming from the north and water inflow through the Channel from the south. For a long time, it was assumed that offshore regions in the North Sea, such as the Dogger Bank, were not affected by environmental changes, induced by human activities. Recently, evidence was presented that the Dogger Bank is an area of special ecological conditions. These results were mainly obtained within the framework of two large interdisciplinary projects at Hamburg University. The present information for the different ecological compartments in the area of the Dogger Bank can be summarised as follows.

\section{CLIMATE}

North Sea surface temperatures from 1902-54 and from 1971-80 (Tomczak \& Goedecke, 1962; Becker et al., 1986) do not show a significant increase. Taylor \& Stephens (1983) mentioned a small increase of surface temperatures of $0.3^{\circ} \mathrm{C}$ in winter and spring in the Southern Bight from 1961 to 1976 . In the summer of 1990, Nielsen et al. (1993) reported temperatures of 10 to $11{ }^{\circ} \mathrm{C}$ from the vertically mixed water at the Dogger Bank, which were similar to the overall surface temperatures of the central southern North Sea. Wind data (Seewetteramt Hamburg; pers comm.) do not show any higher frequency of heavy storms occurring during the eighties than during the fifties. 

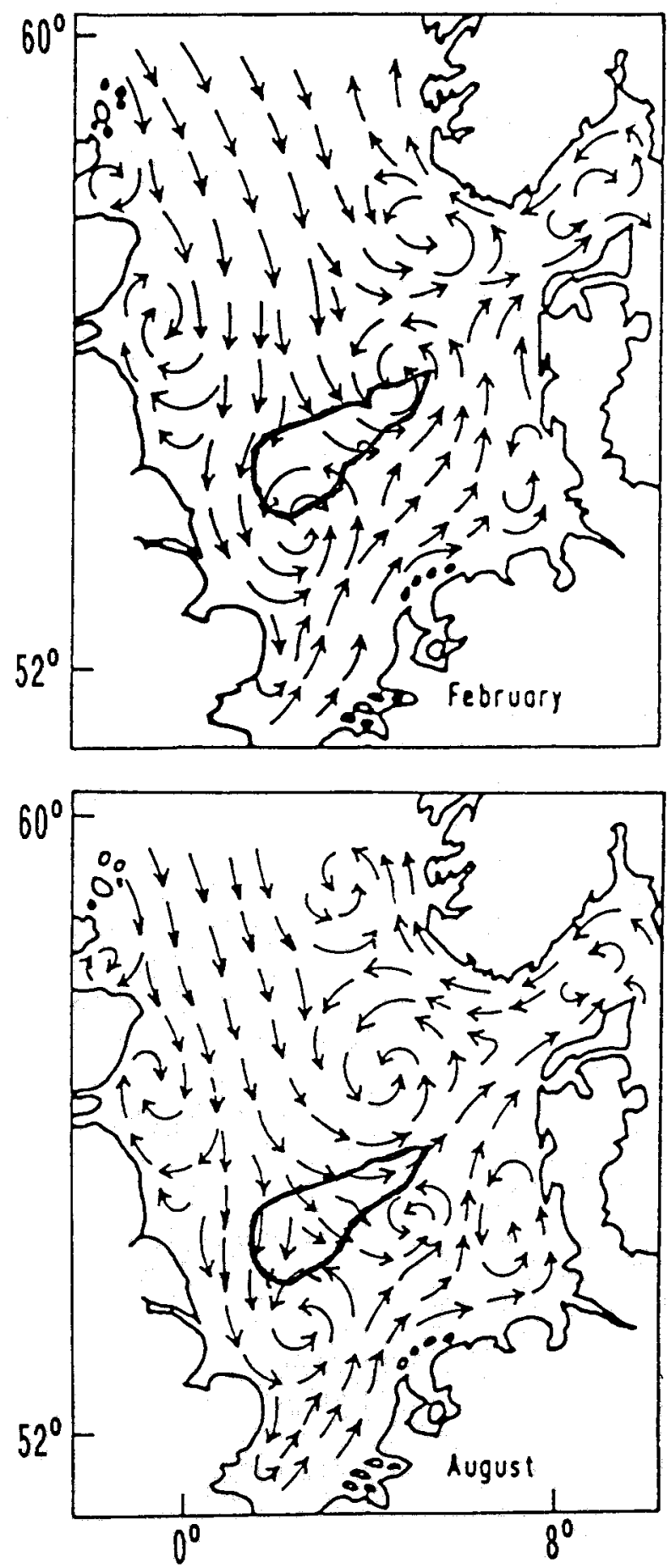

Fig. 1. Residual circulation of the North Sea as inferred by Böhnecke from salinity distributions (Böhnecke, 1922) 


\section{HYDROGRAPHY}

The hydrographic regime of the Dogger Bank is characterized by a complicated regime of currents and eddies. Within the anti-clockwise residual current system of the North Sea, Atlantic water comes from the north and meets the residual currents from the Straits of Dover south of the Dogger Bank (Böhnecke, 1922) (Fig. 1). Eddies are likely to be formed, causing areas of weak currents and increasing sedimentation. A hydrographic model run with 13 years of actual data collected by Hainbucher et al. (1986) indicates the occurrence of eddies in the Dogger Bank region. Nielsen et al. (1993) used a scheme for water column structure from Bo Pedersen (1993) which shows that during summer the Dogger Bank is influenced by water masses reaching the area from the southern central North Sea as well as by those coming from the North, both meeting and mixing at the Bank (Fig. 2).

\section{WATER COLUMN}

Peeters \& Peperzak (1990) and Riegman et al. (1990) investigated nutrient limitation in the central North Sea and found nitrogen to be limiting, in contrast to Si and P in coastal regions. In stratified water during summer, Nielsen et al. (1993) found lowest concentrations of nitrate and phosphate south of the Dogger Bank as well as in the area proper; highest values were found in the bottom water north of the Bank.

Liebezeit $(1988,1993)$ reported high concentrations of dissolved humic compounds on the Dogger Bank as result of riverine input (Fig. 3).

Concentrations of dissolved heavy metals are low in the central North Sea (Kremling et al., 1987; Kremling \& Hydes, 1988; Fileman et al., 1991). In contrast, heavy metals associated with particular matter show elevated concentrations in the Dogger Bank area (Delbeke \& Joiris, 1987; Schmidt \& Dicke, 1988).

\section{SEDIMENTS}

The sediments of the Dogger Bank proper are fine sands with large amounts of shells; the deeper parts around the Bank are muddy fine sands (Figge, pers. comm. in Kröncke, 1991).

Von Haugwitz \& Wong (1988) find tidal currents to be insufficient for sediment transport, but storms and storm-induced currents will erode and resuspend the fine fractions of the sediments.

The $<20 \mu \mathrm{m}$ fractions of sediments in Dogger Bank sediments, especially at the Tail End, contain twice as much organic carbon as those in coastal sediments (Wirth \& Wiesner, 1988) (Fig. 4).

The porewater nutrient concentrations are low compared with other marine sediments, but indicate benthic fluxes of equal importance, compared to those estimated for the Southern Bight of the North Sea (Van Raaphorst et al., 1990).

When compared with coastal sediments, the highest concentrations for lead and cadmium are found in the fine fraction $(<20 \mu \mathrm{m})$ of Dogger Bank and adjacent sediments (Albrecht, 1987; Irion \& Müller, 1987; Kersten \& Klatt, 1988) (Fig. 5). Irion \& Müller (1990) could show, by dated sediment cores, that within the uppermost $10 \mathrm{~cm}$ there is an increase of $100-150 \%$ in lead concentration in the eastern (Fig. $6 \mathrm{a}$ ) and southern part of 


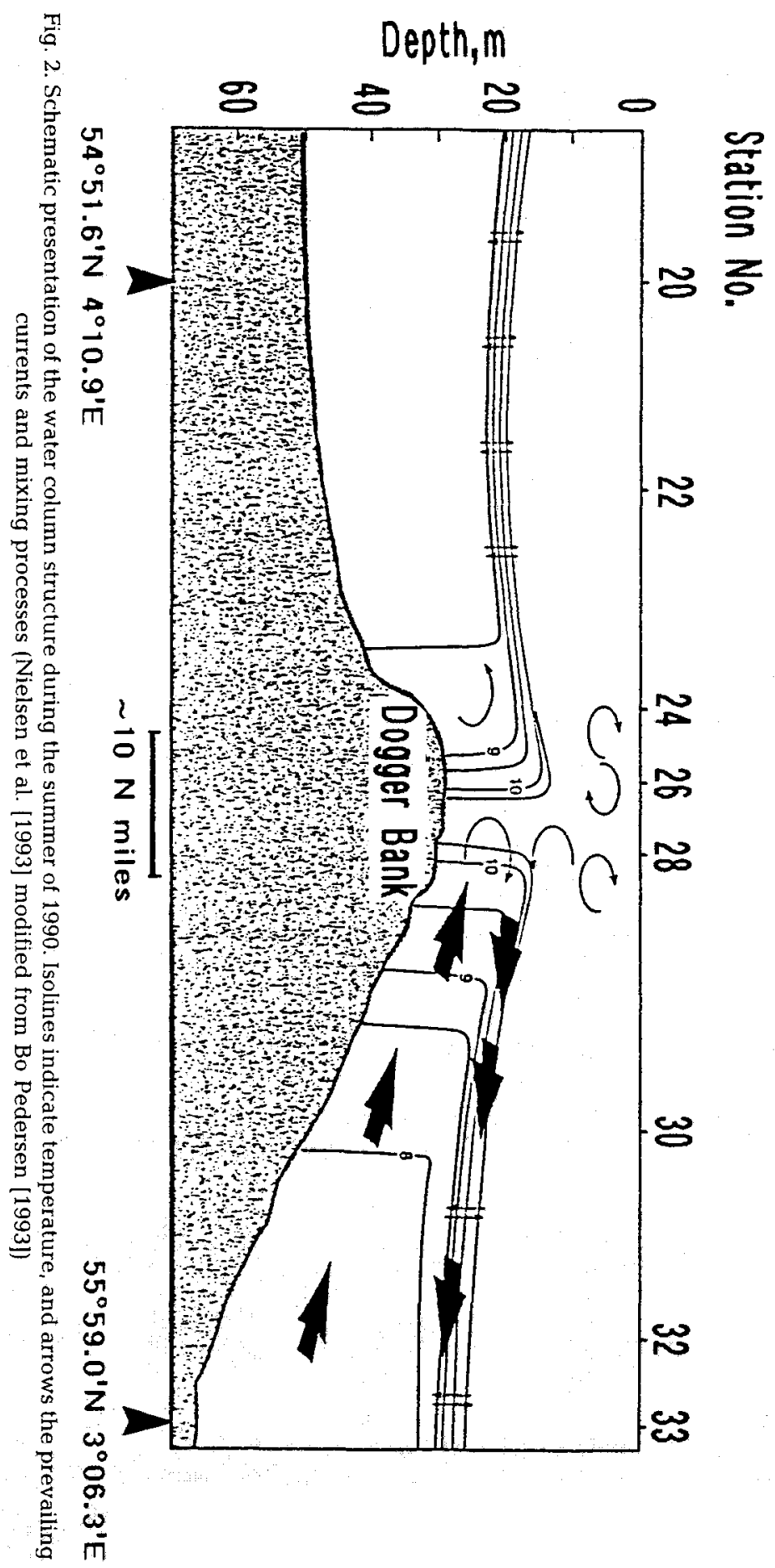



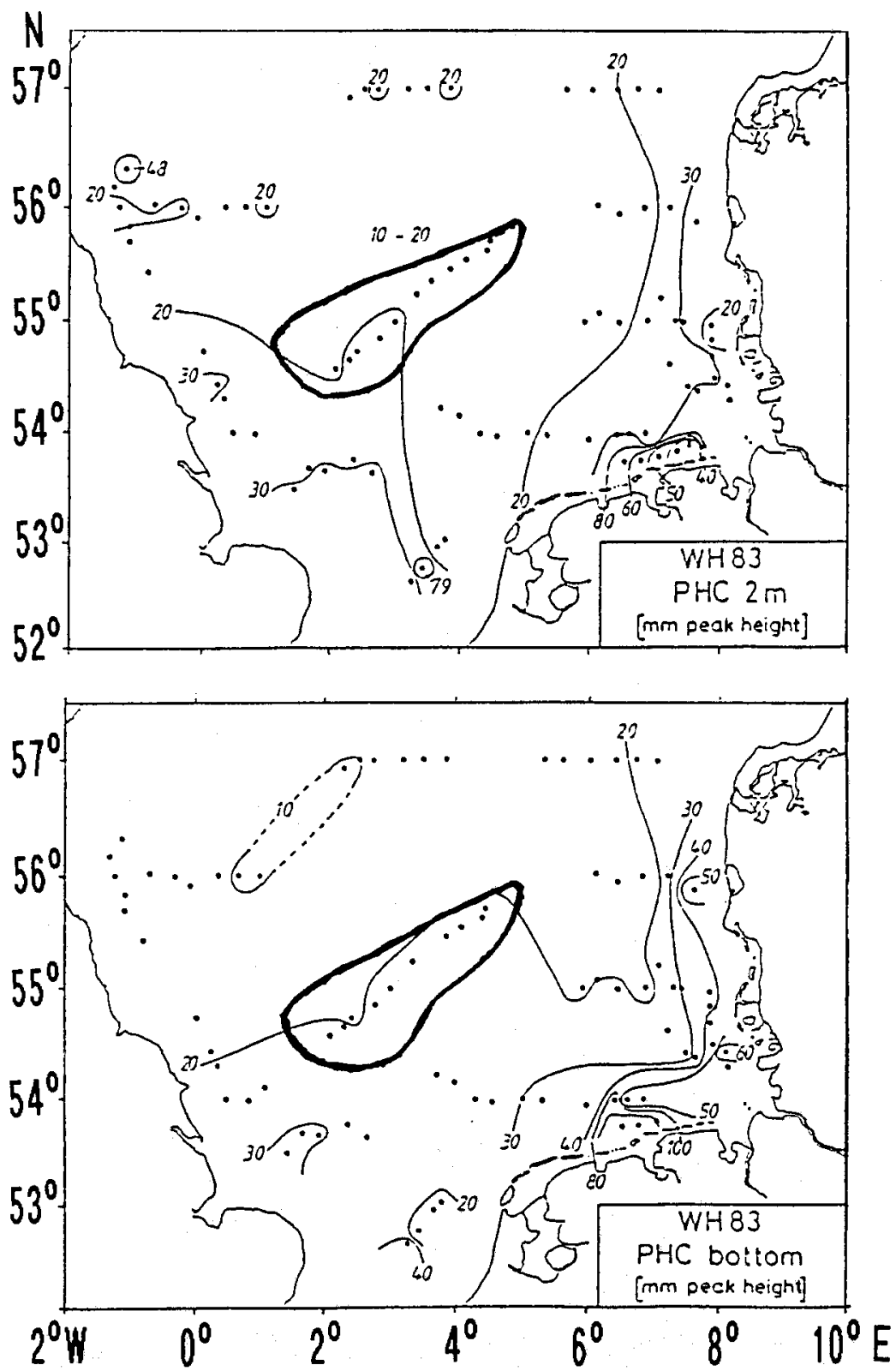

Fig. 3. PHC distributions in surface and bottom waters in June 1987 (Liebezeit, 1993)

the Dogger Bank (Fig. 6b). Kersten \& Kröncke (1991) presented evidence that the fine fraction $(<20 \mu \mathrm{m})$ of the Dogger Bank sediments have lead levels that are twice as high as those in sediments from the German Bight.

Concentrations of several organochlorine pesticides (Lohse, 1988) and polycyclic 


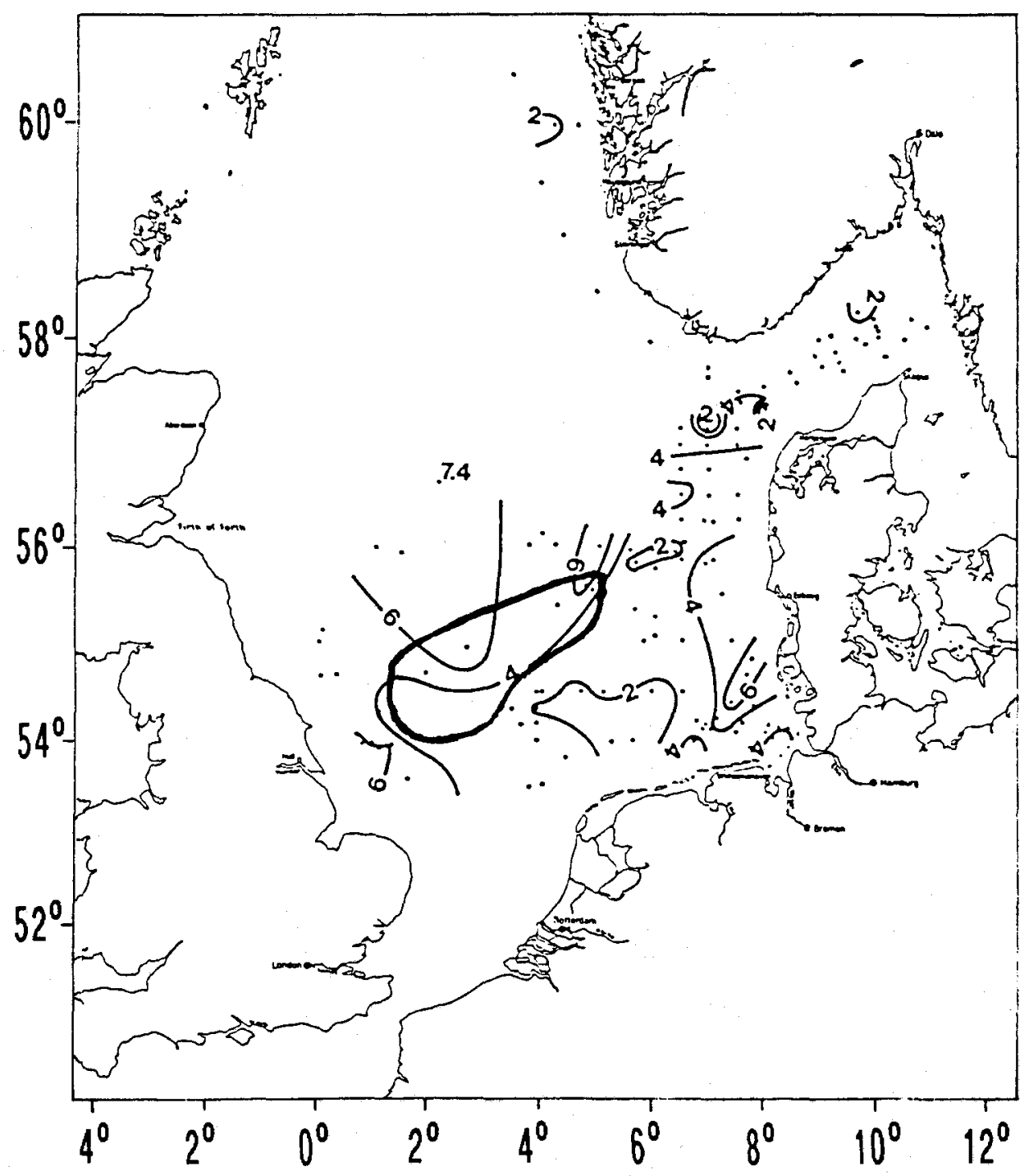

Fig. 4. Regional distribution of total organic carbon $(\%)$ in the $<20 \mu \mathrm{m}$ fraction of sediments (Wirth \& Wiesner, 1988)

aromatic hydrocarbons (Klamer et al., 1990) in sediments of the Dogger Bank are comparable to those of coastal areas.

\section{PHYTOPLANKTON}

The Dogger Bank is a region of high phytoplankton production throughout the year, as indicated by nutrient distribution (Fig. 7) (Brockmann \& Wegner, 1985; Richardson \& Olsen, 1987; Brockmann et al., 1990). Only part of the dense spring blooms is consumed 


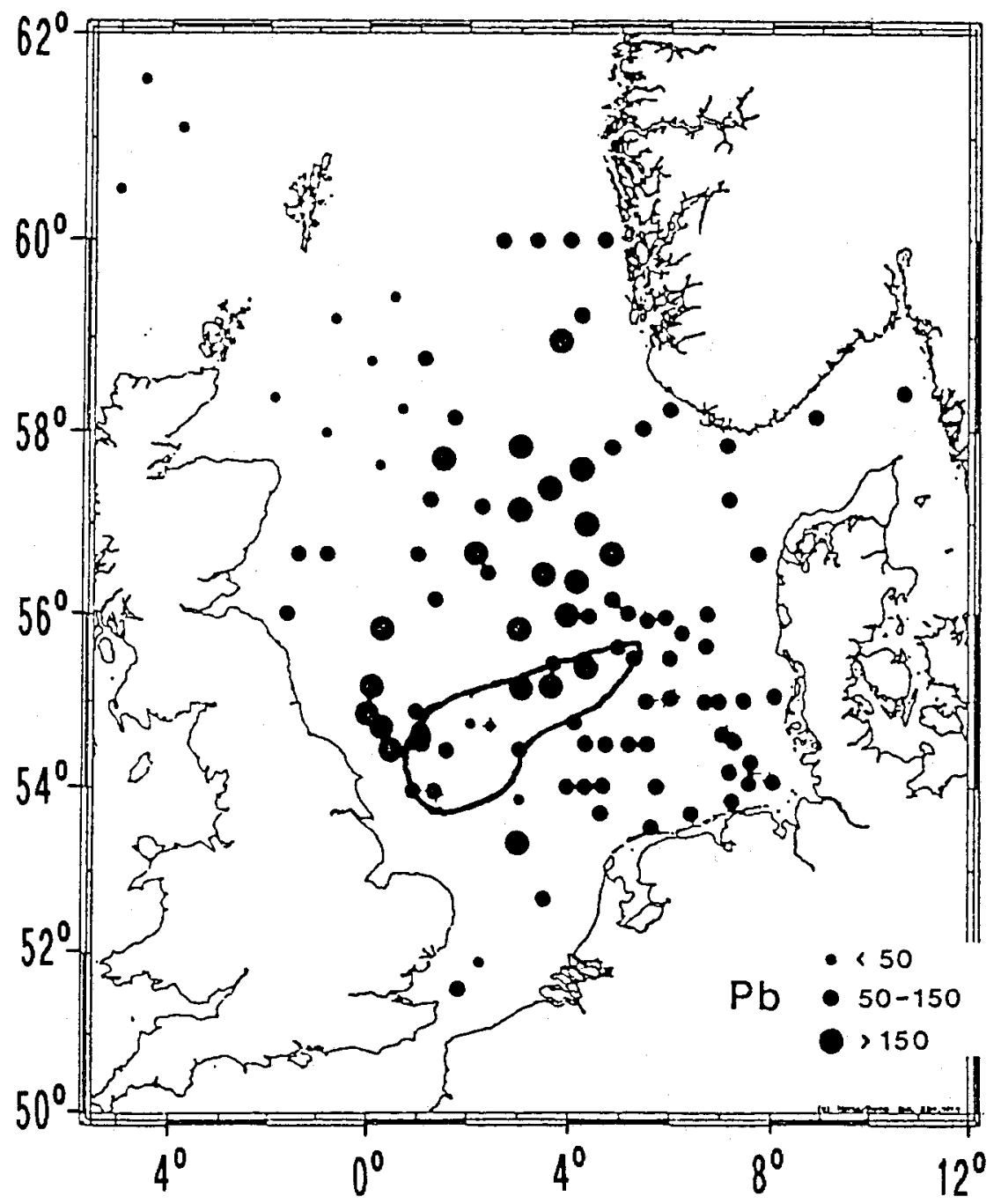

Fig. 5. Lead concentration ( $\mathrm{mg} / \mathrm{kg}$ ) in the $<20 \mu \mathrm{m}$ fraction of sediments (Kersten \& Klatt, 1988)

within the water column; the major part settles to the sediment surface (Nielsen \& Richardson, 1989). Nielsen et al. (1993) reported subsurface phytoplankton blooms during the summer, mainly consisting of small flagellates. During the summer as well, production of grazable phytoplankton does not seem to be sufficient to meet copepod energy requirements. This indicates, in connection with high bacterial biomasses in the water column, the importance of the microbial loop within the carbon cycle.

Concentrations of organochlorines in plankton are highest in the central North Sea (Knickmeyer \& Steinhardt, 1989). 

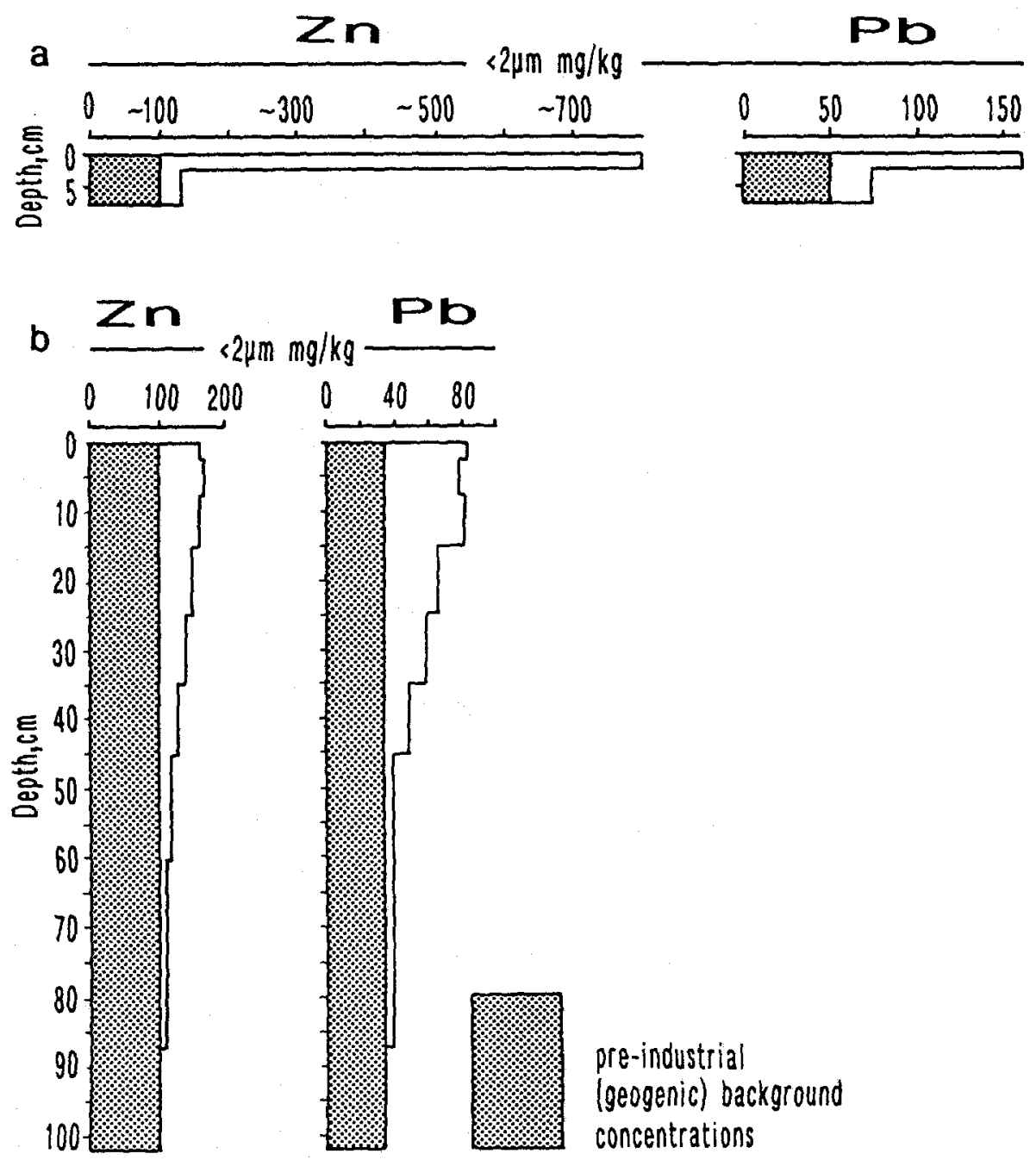

Fig. 6. Zinc and lead concentration $(<2 \mu \mathrm{m}$ fraction, $\mathrm{mg} / \mathrm{kg})$ in sediment cores from the eastern part (a) and south of the Dogger Bank (b) (Irion \& Müller, 1990)

\section{BENTHOS}

A long-term comparison between data from 1950-1954 (Ursin, 1960, Kirkegaard, 1969; Petersen \& Høpner, 1977; Birkett, unpubl. data in Kröncke, 1991) and 1985-87 (Kröncke, 1990, 1992) reveal changes in the macrofauna communities of the Dogger Bank. These are characterized as follows: higher species numbers; increase of opportunistic, short living species; decrease of long-living bivalves and a 2.5- to 8-fold increase in biomass.

The seasonal periodicity within several macrofaunal groups from the Dogger Bank does not show such distinct variations as in the coastal regions. Figure 8 shows the means 
of abundances for each systematic group during the period from May 1985 to April 1987. Crustaceans showed distinct seasonal variations, with reproduction occurring mainly during winter (Fig. 8a, b). Among the polychaetes (Fig. 8c), the Errantia did not show seasonal variations, whereas the Sedentaria were most abundant during summer. Similarly, bivalve (Fig. 8d), echinoid (Fig. 8e) and phoronid (Fig. 8f) abundances were highest in August 1986. It is unknown, whether densities of bivalves and echinoids were correspondingly high in August 1985, because sampling was delayed until October that
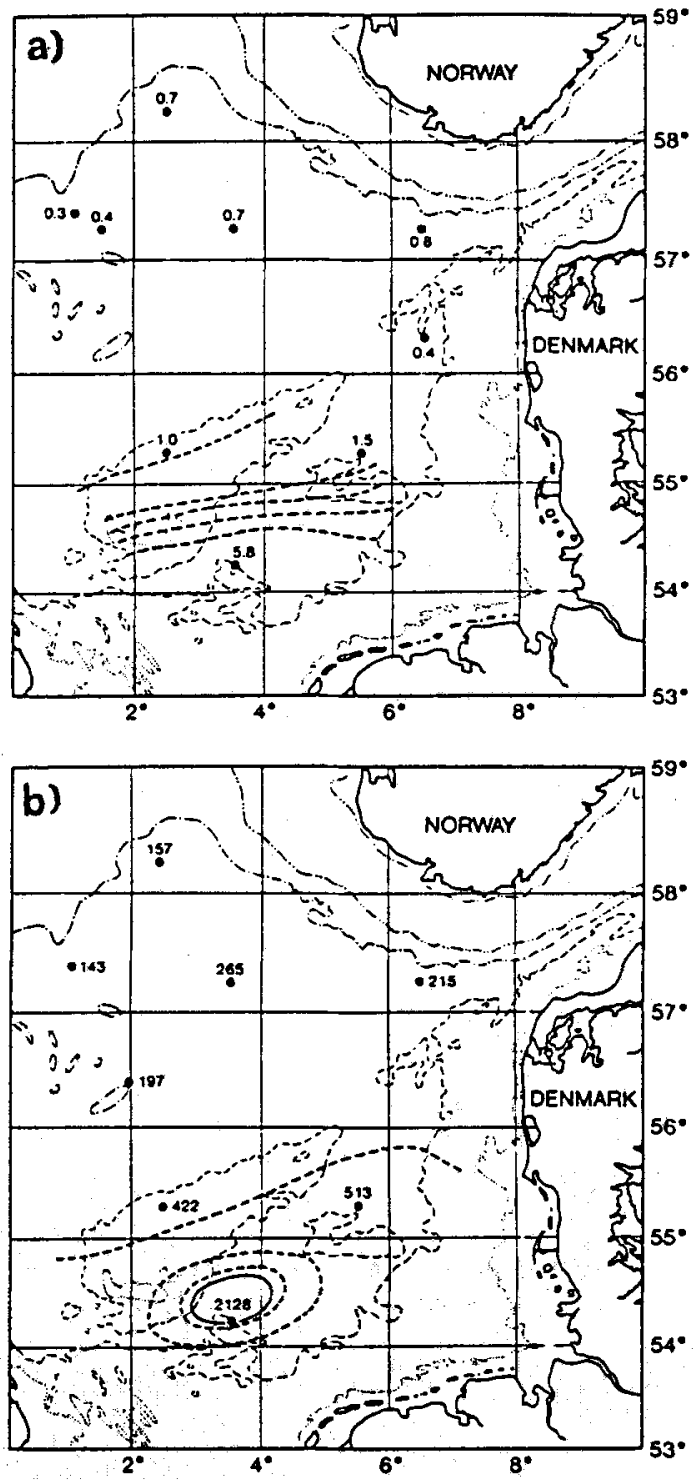

Fig. 7. Distribution of chlorophyll a ( $\mu \mathrm{g} \mathrm{l}^{-1}$ ) (a) ana pnmary proauction $\left(\mathrm{mg} \mathrm{C} \mathrm{C}^{-2} \mathrm{~d}^{-1}\right)$ (b) in February/March 1988 (Nielsen \& Richardson, 1989) 

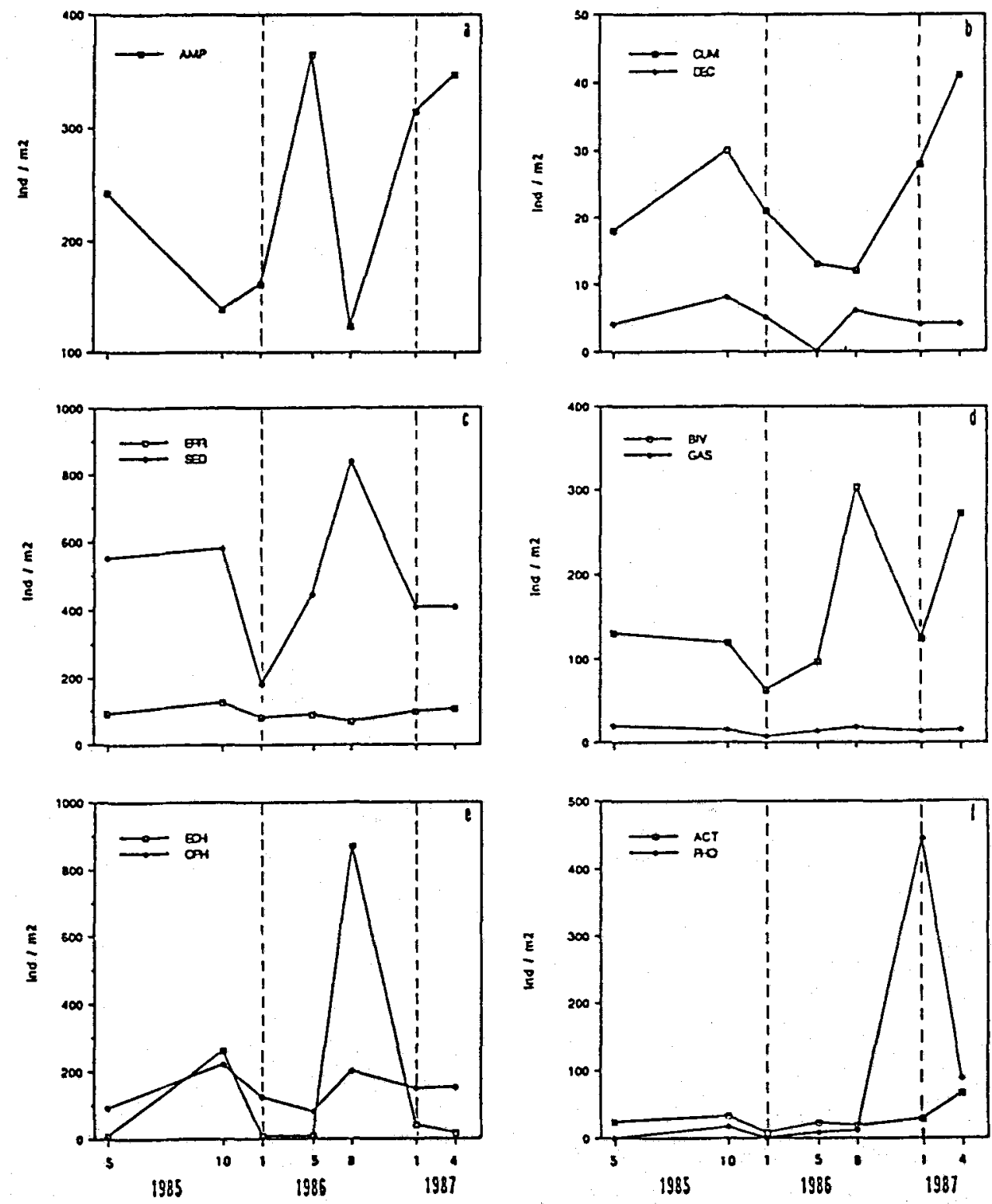

Fig. 8. Mean abundance (individuals per $\mathrm{m}^{2}$ ) for macrofaunal systematic groups from May 1985 to April 1987. a: Amphipoda; b: Cumacea, Decapoda and Mysidacea; c: Polychaeta: Errantia and Sedentaria; d: Bivalvia and Gastropoda; e: Echinoidea and Ophiuroidea; $f$ : Actiniaria and Phoronida (Kröncke \& Knust, 1992): 

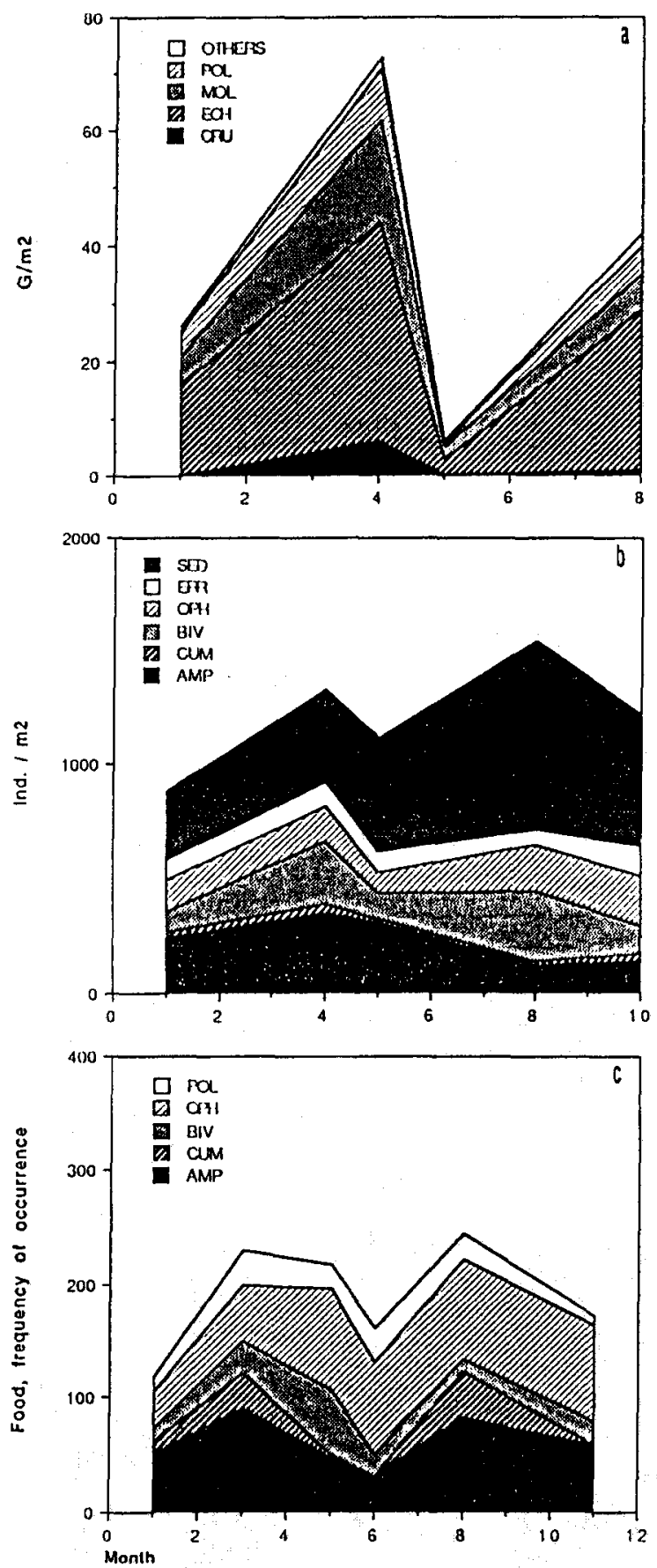

Fig. 9. Mean monthly macrofaunal biomass (a) and abundance (b) and stomach contents of dab (Limanda limanda) (c) from May 1985 to April 1987. a: Crustacea, Echinodermata, Mollusca, Polychaeta, Others; b: Amphipoda, Cumacea, Bivalvia, Ophiuroidea, Polychaeta: Errantia and Sedentaria; c: Amphipoda, Cumacea, Bivalvia, Ophiuroidea, Polychaeta (Kröncke \& Knust, 1992) 
year. If the densities were high, autumn is identified as a period of severe mortality for these groups, which, for example, may be due to intense predation by dab.

In contrast, abundances of the remaining groups (i.e. vagile polychaetes, gastropods, ophiurids and actinians, Fig. $8 \mathrm{c}, \mathrm{d}$, e and f) remain uniformly low during the study period.

Figure 9 shows the seasonal variations in mean biomass and abundance of potential prey items and stomach contents of dab (Limanda limanda) for the northeastern part of the Dogger Bank over three years. All parameters follow a bimodal distribution, peaking in spring and in summer. The lowest values are recorded in early summer.

Several macrofauna species here show higher concentrations of heavy metals (Fig. 10) (Kröncke, 1987; Borchardt et al., 1988; Karbe et al., 1988; Everaarts \& Fischer, 1989; Everaarts et al., 1990) and organochlorines (Knickmeyer \& Steinhardt, 1988a, b) than in coastal regions.
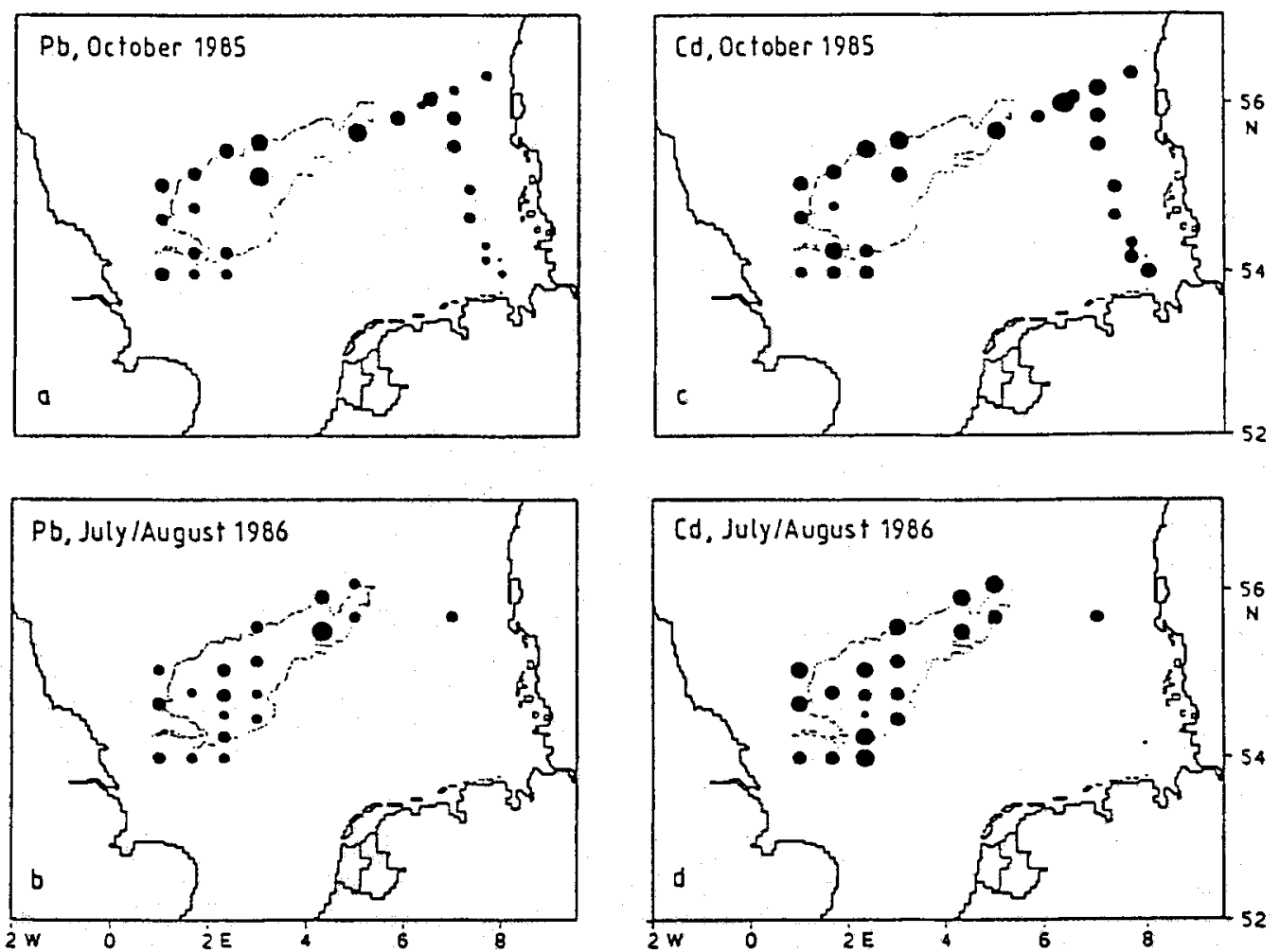

$\mathrm{Pb}: \quad 6.5 \mathrm{mg} / \mathrm{kg}$ dry weight

Cd:

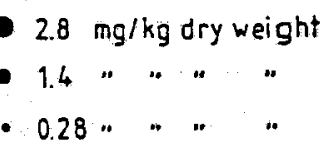

Fig. 10. Lead and cadmium concentrations (mg/kg dry weight) in the polychaete Nephtys spp. measured in October 1985 and August 1986 (Kröncke, 1987) 


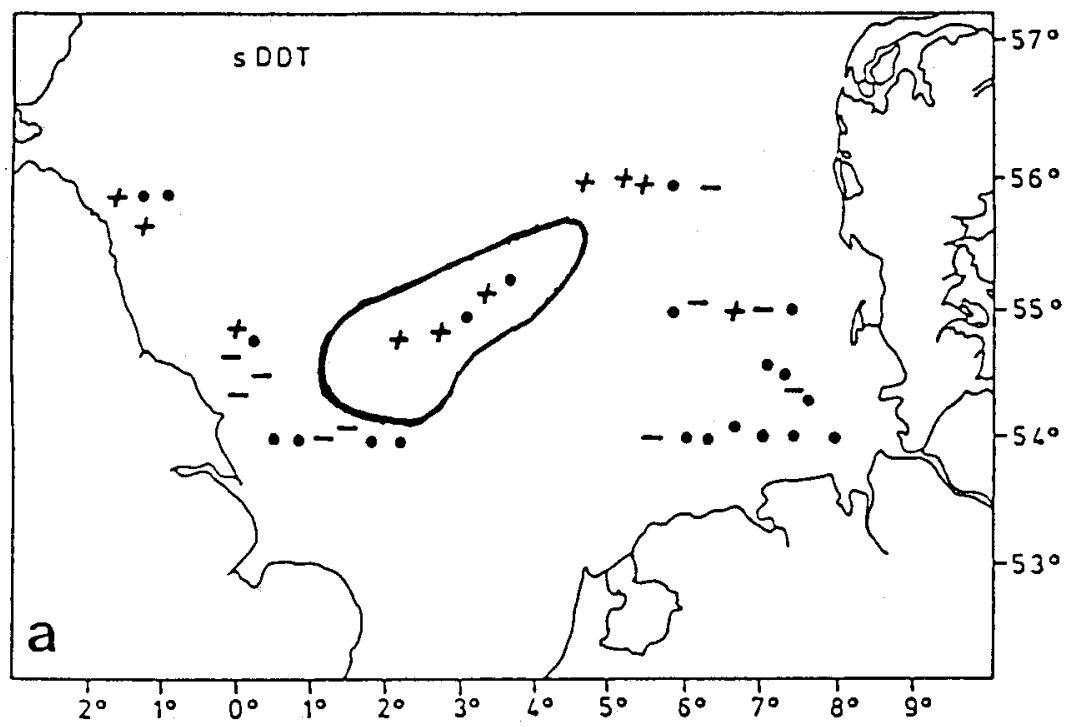

$-=320-450,0=450-700, t=700-1800 \mu \mathrm{g} / \mathrm{kg}$ liver fat

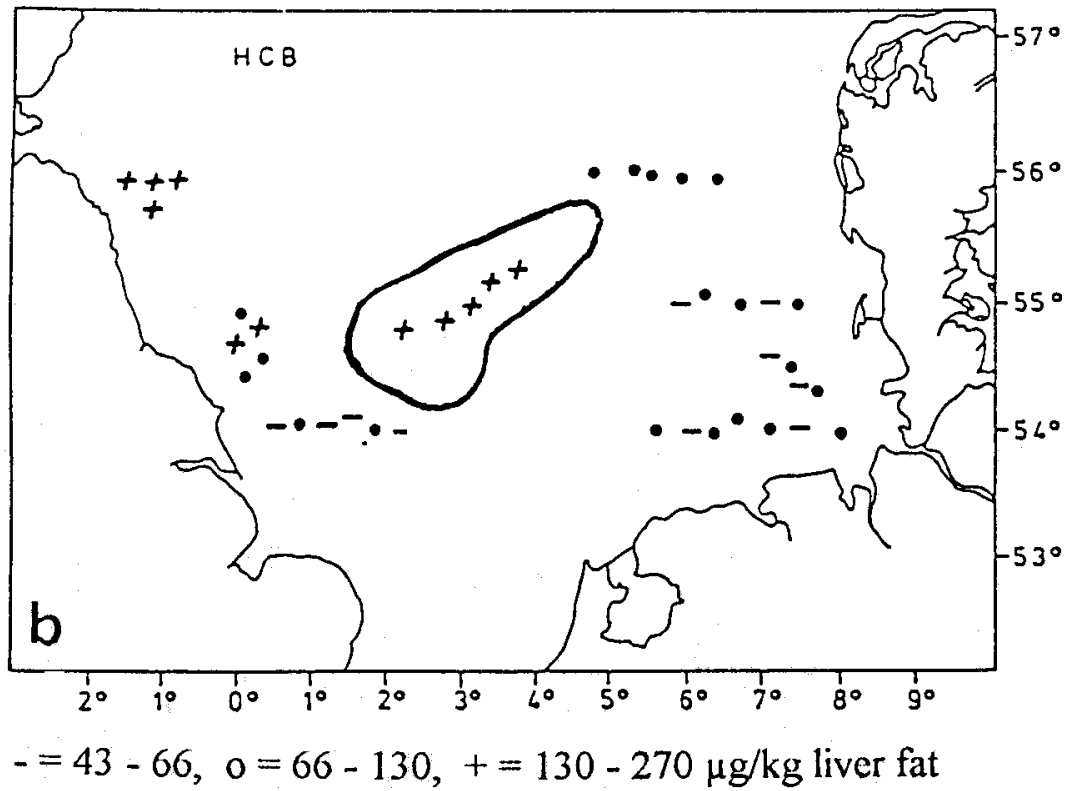

Fig. 11. Prevalence of ulcerations (a) and epidermal papilloma (b) on dab (Limanda limanda) (Dethlefsen et al., 1987) 


\section{FISH}

Dethlefsen et al. (1987) found higher percentages of several diseases of dab (Limanda limanda) on the Dogger Bank (Fig. 11). Claussen (1988) measured the highest concentrations of $\mathrm{Cd}$ and $\mathrm{Pb}$ in dab compared with fishes from the German Bight or Danish waters. Büther (1988) analysed organochlorine pesticides in dab and found no decreasing gradient for several components towards the open sea (Fig. 12).

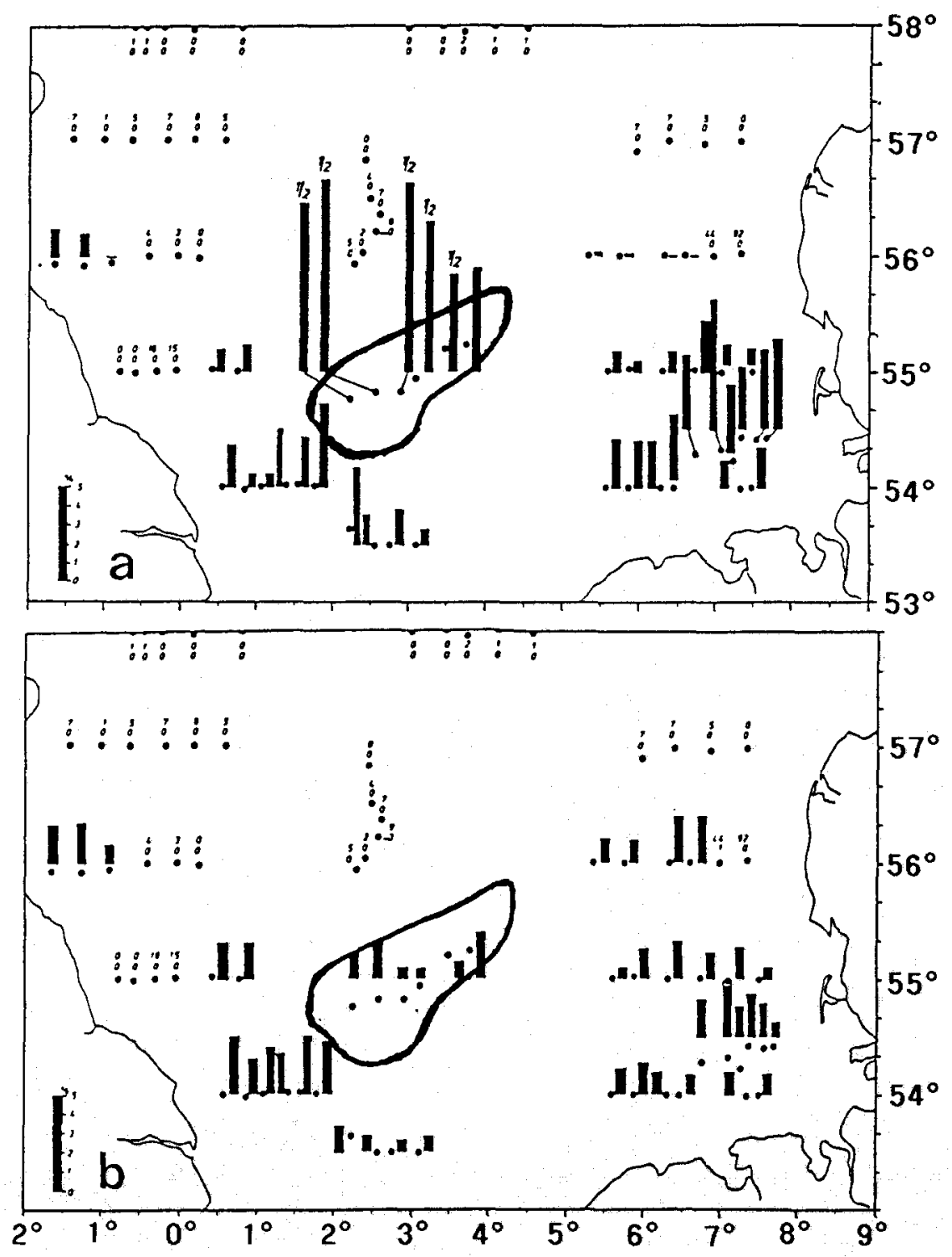

Fig. 12. Distribution of DDT-derivates (a) and hexachlorobenzene (HCB) (b) in livers of dab (Limanda limanda) (Büther, 1988) 


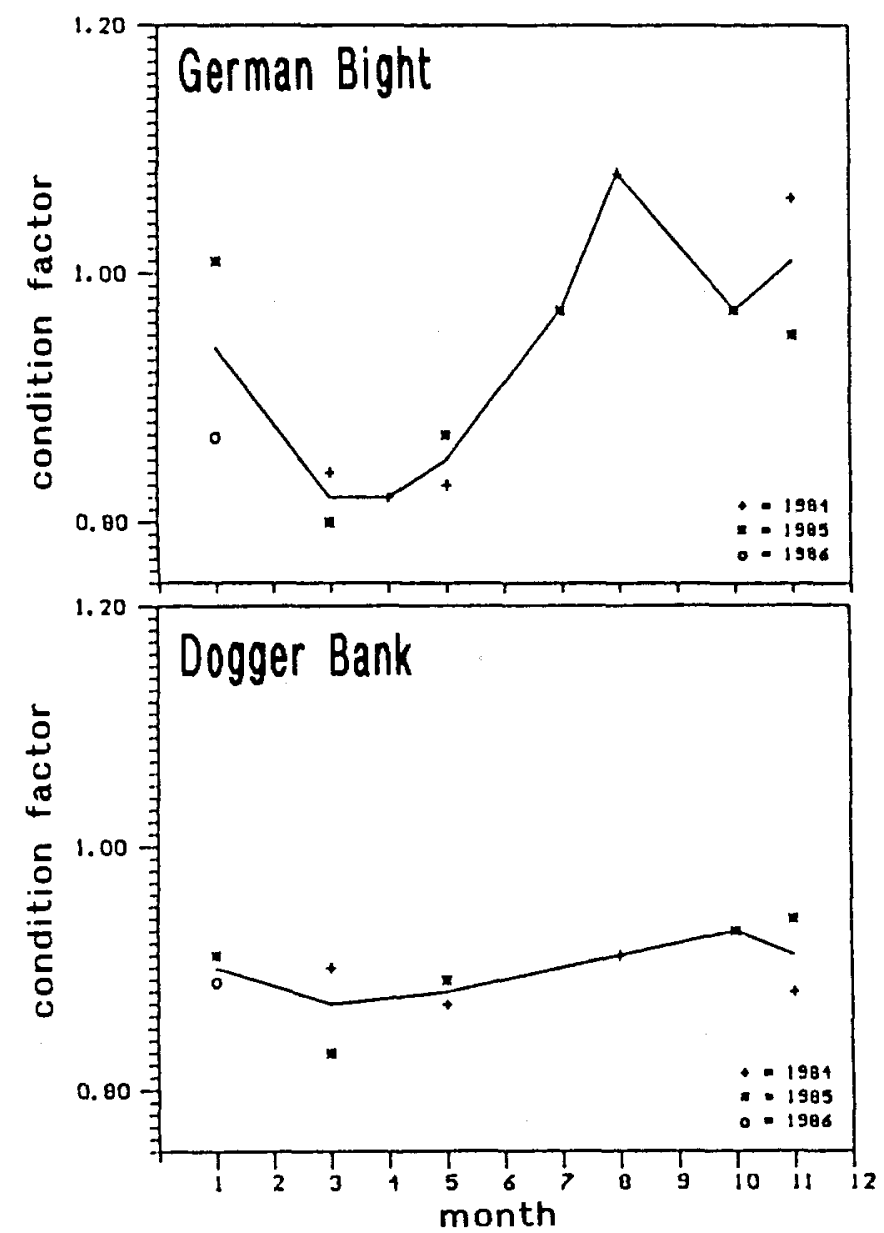

Fig. 13. Condition factor of female dab (Limanda limanda) from the German Bight and the Dogger Bank (Knust, 1990a)

Knust $(1987,1990 \mathrm{a}, \mathrm{b})$ found lower condition and gonadosomatic indices in dab from the Dogger Bank, when compared with dab from the German Bight. The condition factor did not follow any seasonal periodicity (Fig. 13).

\section{FISHERIES}

Purdom \& Garrod (1990) reported an increase in fishery for haddock, cod and plaice on the Dogger Bank since 1950. In contrast, Rauck, Daan and Pope (pers. comm.) stated that the Dogger Bank had been unimportant for commercial fisheries for the past 10 years, and the above mentioned increase was negligible in relation to the whole North Sea. Sandeel fishery takes place in spring around the Dogger Bank with light gear that should not be damaging to the sea floor (Popp Madsen, pers. comm.). 


\section{DISCUSSION}

The present literature gives evidence that the ecology on the Dogger Bank differs in many respects from that of coastal regions. Primary production occurs throughout the year with maximum bloom density occurring in winter and spring. High bacterial biomasses indicate the importance of the microbial loop within the carbon cycle in the water column as well as in benthic fluxes.

In contrast to the German Bight, where macrofaunal abundance showed a distinct unimodal periodicity with maxima in summer and minima in winter (Rachor \& Gerlach, 1978), the permanent food supply might result in the bimodal pattern in both abundance and biomass, with one maximum in spring and another in autumn on the Dogger Bank. The stomach contents of dab varied correspondingly. In contrast to the German Bight, the additional supply of food in spring on the Dogger Bank might explain why dab exhibit a constant condition factor in this area throughout the year.

The changes found over the last 35 years in the macrofauna communities of the Dogger Bank fit well into the continuum given by Pearson \& Rosenberg (1978) for communities under increasing eutrophication of the environment. Duineveld et al. (1987) mentioned a drastic increase of ophiurids in the whole southern North Sea, due to enrichment of organic matter. The Dogger Bank is influenced by two different water masses. The northern part is influenced by the nutrient- and contaminant-rich Atlantic bottom waters, responsible for high concentrations of total organic carbon and pollutants on the Fishers Bank north of the Dogger Bank. On the other hand, the Dogger Bank proper and the southern part are influenced by the hydrological regime of the central southern North Sea, which transports nutrients into the area from the English coast and the Channel towards the German Bight. Therefore, changes in the macrofauna communities at the Dogger Bank reflect the increasing input of organic material into this area comprised of sandy sediments. In addition, a high contamination of the $<20 \mu \mathrm{m}$ fraction of sediment on the Dogger Bank is present. Contamination increases along the food web via macrofaunal ingestion of the fine fraction of sediments and the feeding of dab on macrofauna.

For the time being, existing data sets for the Dogger Bank are limited and can only partly describe the ecological situation of this area. One should, therefore, intensify investigations on the Dogger Bank to estimate the elasticity of the system as a part of the polluted North Sea. More information is needed pertaining to sediment structure, sediment movements, input and resuspension of small sediment fractions, persistance of organic matter in the food web, succession of the benthic communities under increasing organic input and the bioavailability of contaminants for the organisms.

Acknowledgements. Thanks are due to I. Hoppe and J. Heuers for help in sorting the macrofauna samples from the Dogger Bank, and to M. Opitz and T. Knütel for weighing the biomass. We thank R. Flügel for improving the figures.

\section{LITERATURE CITED}

Albrecht, H., 1987. Sediment studies in the German Bight and adjacent areas of the North Sea. ICES Coop. Res. Rep. 150, 112-131.

Becker, G. A., Frey H. \& Wegner, G., 1986. Atlas der Temperatur an der Oberfläche der Nordsee. Dt. hydrogr. Z., Erg.-H. (Reihe B) 17, 1-127. 
Böhnecke, G., 1922. Salzgehalt und Strömungen der Nordsee. - Veröff. Inst. Meeresk., Univ. Berlin (A) $10,1-34$.

Bo Pedersen, F., 1993. The oceanographic and biological tidal cycle in shallow sea fronts in the North Sea and in the English Channel. - Estuar. coast. Shelf Sci., in press.

Borchardt, T., Burchert, S., Hablizel, H., Karbe, L. \& Zeitner, R., 1988. Trace metal concentrations in mussels: comparison between estuarine, coastal and offshore regions in the southeastern North Sea from 1983 to 1986. - Mar. Ecol. Prog. Ser. 42, 17-31.

Brockmann, U. \& Wegner, G., 1985. Hydrography, nutrient and chlorophyll distribution in the North Sea in February 1984. - Arch. FischWiss. 36, 27-45.

Brockmann, U., Laane, R. W. P. M. \& Postma, H., 1990. Cycling of nutrient elements in the North Sea. - Neth. J. Sea Res. 26, 239-264.

Büther, H., 1988. Distribution of chlorinated organic compounds in livers of dab (Limanda limanda) of the southern and central North Sea. - Mitt. geol.-paläont. Inst. Univ. Hamb. 65, 497-541.

Claussen, T., 1988. Characteristic levels and spatial distribution of trace metals in flatfish (dab, Limanda limanda) from the German Bight and the Southern North Sea. - Mitt. geol.-paläont. Inst. Univ. Hamb. $65,467-496$.

Delbeke, K. \& C. Joiris, 1987. Accumulation mechanisms and geographical distribution of PCBs in the North Sea. In: Environmental protection of the North Sea. Ed. by R. J. Newman \& A. R. Agg. Heinemann, Oxford, 771-779.

Dethlefsen, V., Watermann, B. \& Hoppenheit, M., 1987. Diseases of North Sea dab (Limanda limanda) in relation to biological and chemical parameters. - Arch. FischWiss. 37, $107-237$.

Duineveld, G. C. A., Künitzer, A. \& Heyman, R. P., 1987. Amphiura filiformis (Ophiuroidea: Echinodermata) in the North Sea. - Neth. J. Sea. Res. 21, 317-329.

Everaarts, J. M. \& Fischer, C. V., 1989. Micro contaminants in surface sediments and macrobenthic invertebrates of the North Sea. - NIOZ-Rapp. 1989-6, 1-44.

Everaarts, J. M., Otter, E. \& Fischer, C. V., 1990. Cadmium and polychlorinated biphenyls: different distribution pattern in North Sea benthic biota. - Neth. J. Sea Res. 26, 75-82.

Fileman, C. F., Althaus, M., Law, R. J. \& Haslam, I., 1991. Dissolved and particulate trace metals in surface waters over the Dogger Bank, Central North Sea. - Mar. Pollut. Bull. 22, 241-244.

Hainbucher, D., Backhaus, J. O. \& Pohlmann, T., 1986. Atlas of climatological and actual seasonal circulation patterns in the North Sea and adjacent shelf regions: 1969-1981. - Tech. Rep. Inst. Meeresk. Hamburg 1-86, 1-201.

Haugwitz, W. von \& Wong, H. K., 1988. The Dogger Bank: seismic stratigraphy and holocene sedimentation. - Mitt. geol.-paläont. Inst. Hamb. 65, 409-422.

Irion, G. \& Müller, G., 1987 . Heavy metals in surficial sediments of the North Sea. In: Heavy metals in the environment. Ed. by S. E. Lindberg \& T. C. Hutchinson. CEP Consultants, Edinburgh 2 , $38-41$

Irion, G. \& Müller, G., 1990. Sedimentary processes in the North Sea as revealed from heavy metal distribution in sediment cores. - C.M./ICES, E:16, 1-8.

Karbe, L., Gonzalez-Valero, J., Borchardt, T., Dembinski, M., Duch, A., Hablizel, H. \& Zeitner, R., 1988. Heavy metals in fish and benthic organisms from the northwestern, central and southern North Sea: regional patterns comparing dab, Blue Mussel and Hermit Crab. - C.M./ICES, E:22, $1-14$.

Kersten, M. \& Klatt, V., 1988. Trace metal inventory and geochemistry of the North Sea shelf sediments. - Mitt. geol.-paläont. Inst. Univ. Hamb. 65, 289-311.

Kersten, M. \& Kröncke, 1., 1991. Bioavailability of lead in North Sea sediments. - Helgoländer Meeresunters. 45, 403-409.

Kirkegaard, J. B., 1969. A quantitative investigation of the central North Sea polychaeta. - Spolia zool. Mus. haun. 29, 1-285.

Klamer, J. C., Hull, R. N., Laane, R. W. P. M. \& Eisma, D., 1990. The distribution of heavy metals and polycyclic aromatic hydrocarbons in the sediments of the Oyster Grounds (North Sea). - Neth. J. Sea Res. $26,83-87$.

Knickmeyer, R. \& Steinhardt, H., 1988a. Cyclic organochlorines in the hermit crab Pagurus bernhardus and Pagurus pubescens from the North Sea. - Neth. J. Sea Res. 22, 237-251.

Knickmeyer, R, \& Steinhardt, H., 1988b. Seasonal differences of cyclic organochlorines in eggs of the hermit crab Pagurus bernhardus L. from the North Sea. - Sarsia 73, 291-298. 
Knickmeyer, R. \& Steinhardt, H., 1989. Cyclic organochlorines in plankton from the North Sea in spring. - Estuar coast. Shelf Sci. 28, 117-127.

Knust, R., 1987. Seasonal changes in feeding, condition and gonadosomatic index of dab (Limanda limanda). - C.M./ICES, G:54, 1-13

Knust, R., 1990a. Food and condition of dab Limanda limanda from the Dogger Bank and the German Bight. - C.M./ ICES, G:62, 1-7.

Knust, R., 1990b. Ernährung der Kliesche (Limanda limanda) in der zentralen und südlichen Nordsee und die Bedeutung des Ernährungszustandes für die Erkrankungen dieses Fisches. Veröff. Inst. Küst. Binnenfisch. 102, 1-184.

Kremling, K. \& Hydes, D., 1988. Summer distribution of dissolved $\mathrm{Al}, \mathrm{Cd}, \mathrm{Co}, \mathrm{Cu}, \mathrm{Mn}$, and $\mathrm{Ni}$ in surface waters around the British Isles. - Cont. Shelf Res. 8, 89-105.

Kremling, K., Wenck, A. \& Pohl, C., 1987. Summer distribution of dissolved Cd, Co, Cu, Mn, and Ni in central North Sea waters. - Dt. hydrogr. Z. 40, 103-113.

Kröncke, I., 1987. Lead and cadmium concentrations in selected macrofauna species from the Dogger Bank and the eastern North Sea. - Helgoländer Meeresunters. 41, 465-475.

Kröncke, I., 1990. Macrofauna standing stock of the Dogger Bank. A comparison: II. 1951-52 versus 1985-87. - Neth. J. Sea Res. 25, 189-198.

Kröncke, I., 1991. The macrofauna distribution on the Dogger Bank in April/May 1985-87 (with an annex of unpublished data from BIRKETT of April/May 1952-54). - Ber. Biol. Anst. Helgoland 8, $1-137$

Kröncke, 1., 1992. Macrofauna standing stock of the Dogger Bank. A comparison: III. 1950-54 versus 1985-87. A final summary. - Helgoländer Meeresunters. 46, 137-169.

Kröncke, I. \& Knust, R., 1992. Seasonal variations in macrofaunal abundance on the Dogger Bank in relationship to stomach content of dab (Limanda limanda).- C.M./ICES, G:80, 1-10.

Liebezeit, G., 1988. Distribution of dissolved humic compounds in the southern North Sea. - Mitt. geol.-paläont. Inst. Univ. Hamb. 65, 153-162.

Liebezeit, G., 1993. Fluorimatic analysis of dissolved and particulate humic compounds in the North Sea in May/June 1987. - Dt. hydrogr, Z. 45, 255-266.

Lohse, J., 1988. Distribution of organochlorine pollutants in North Sea sediments. - Mitt. geol.paläont. Inst. Univ. Hamb. 65, 345-365.

Nielsen, T. Gissel \& Richardson, K., 1989. Food chain structure of the North Sea plankton communities: seasonal variations of the role of the microbial loop. - Mar. Ecol. Prog. Ser. 56, 75-87.

Nielsen, T. Gissel, Lokkegaard, B., Richardson, K., Bo Pedersen, F. \& Hansen, L., 1993. Structure of plankton communities in the Dogger Bank area (North Sea) during a stratified situation. - Mar. Ecol. Prog. Ser. 95, 115-131.

Pearson, T. H. \& Rosenberg, R., 1978. Macrobenthic succession in relation to organic enrichment and pollution of the marine environment. - Oceanogr. mar. Biol. 16, 229-311.

Peeters, J. C. H. \& Peperzak, L., 1990. Nutrient limitation in the North Sea: a bioassay approach. Neth. J. Sea Res, 26, 61-73.

Petersen, G. Høpner, 1977. The density, biomass and origin of the bivalves of the central North Sea. - Meddr Danm. Fisk.- og Havunders. 7, 221-273.

Purdom, C. E. \& Garrod, D. J., 1990. Fisheries on the Dogger Bank. - C.M./ICES, G:66, 1-5.

Raaphorst, W. van, Kloosterhuis, H. T., Cramer, A. \& Bakker, K. J. M., 1990. Nutrient early diagenesis in the sandy sediments of the Dogger Bank area, North Sea: pore water results. Neth. J. Sea Res. 26, 25-52.

Rachor, E. \& Gerlach, S. A., 1978. Changes of macrobenthos in a sublittoral sand area of the German Bight, 1967 to 1975. - Rapp. P.-v. Reun. Cons. int. Explor. Mer 172, 418-431.

Richardson, K. \& Olsen, O. V., 1987. Winter nutrient concentrations and primary production in the eastern North Sea. - C.M./ICES, C:23, 1-14.

Riegman, R., Colijn, F., Malschaert, J. F. P., Kloosterhuis, H. T. \& Cadee, G. C., 1990. Assessment of growth rate limiting nutrients in the North Sea by the use of nutrient-uptake kinetics. - Neth. J. Sea Res. $26,53-60$.

Schmidt, E. \& Dicke, M., 1988. Schwermetalle im Wasser. In: Zirkulation und Schadstoffumsatz in der Nordsee. ZISCH-Abschlußbericht. Institut. f. Meereskunde, Hamburg, 207-220.

Taylor, A. H. \& Stephens, J. A., 1983. Seasonal and year-to-year changes in the temperatures of the English Channel and the Southern North Sea, 1961-1976: a budget. - Oceanologica Acta 6, 63-72. 
Tomczak, G. \& Goedecke, E., 1962. Monatskarten der Temperatur der Nordsee, dargestellt für verschiedene Tiefenhorizonte. - Dt. hydrogr. Z. Erg.-H. (Reihe B) 7, 1-16.

Ursin, E., 1960. A quantitative investigation of the echinoderm fauna of the central North Sea. Meddr Danm. Fisk.- og Havunders. 2, 1-204.

Wirth, H. \& Wiesner, M. G., 1988. Sedimentary facies in the North Sea. - Mitt. geol.-paläont. Inst. Univ. Hamb. 65, 269-287. 